\title{
PERUSAHAAN MODAL VENTURA PERSPEKTIF EKONOMI SYARIAH
}

\author{
Dewi K umalasari \\ Prodi Ekonomi Syariah \\ Fakultas Syariah IA I Uluwiyyah M ojokerto \\ e-mail: dewikumalasarinyafulka@gmail.com
}

\begin{abstract}
In Indonesia, so many financial institutions that provide financing, either in the form of equity or in the form of loan. Financial institutions that provide financing in the form of loan, such as financial institutions of Islamic banks, require borrower to provide collateral and require financing prospective customer to attach financial statement of the business operated. The problem arises when the company that is going to start a business wants to apply for a loan to the Islamic bank, which new company has no the financial statements at all, even has no collateral required by the Islamic bank. Financing is one of the important things for companies that are just about to start a business, but it is difficult to obtain. Are there financial institutions, particularly the Islamic financial institutions that provide loan without requiring collateral or attach the financial statements of the business? A new company which is just opening a business, and have difficulties in getting funding, but still want to obey sharia principles, the right solution is a Sharia venture capital. On the one hand, the presence of sharia venture capital not only merely accommodates the interest of Muslims, but also emphasises on factors of advantage and benefit by providing financing help for economic activities, both small, medium, and large enterprises with the principles of sharia compliance. Venture capital is a form of the provision of capital to a company in the form of capital which, in this case, the company does not require collateral, like in Islamic banking. The company that wants to borrow from financial institutions, but do not want to earn or pay interest, as in conventional bank, the sharia venture capital sharia is the solution. Furthermore, to introduce and expand the knowledge of venture capital, especially sharia venture capital, this paper will discuss in one paper entitled sharia venture capital perspective on sharia economics.
\end{abstract}

Keywords: Sharia economics, venture capital

\section{Pendahuluan}

Di Indonesia begitu banyak lembaga keuangan yang memberikan pembiayaan, baik dalam bentuk penyertaan modal maupun dalam bentuk pinjaman. Untuk lembaga keuangan yang memberikan pembiayaan dalam bentuk pinjaman, seperti lembaga keuangan bank syariah mengharuskan peminjam untuk memberikan jaminan (agunan) dan mensyaratkan calon nasabah pembiayaan untuk melampirkan laporan keuangan dari usaha yang sudah dijalankan. Muncul masalah ketika perusahaan yang baru mau memulai usahanya hendak mengajukan pinjaman ke bank syariah, di mana perusahaan baru tersebut belum memiliki laporan keuangan sama sekali, bahkan mungkin tidak memiliki jaminan (agunan) yang 
dipersyaratkan oleh bank Syariah tersebut. Pembiayaan merupakan salah satu hal penting bagi perusahaan yang baru saja akan memulai usaha, akan tetapi hal tersebut sulit didapatkan. Adakah lembaga keuangan, khususnya lembaga keuangan syariah yang memberikan pinjaman tanpa mempersyaratkan jaminan (agunan) atau harus melampirkan laporan keuangan dari usahanya? Untuk perusahaan yang baru membuka usaha, dan mengalami kesulitan dalam mendapatkan pendanaan akan tetapi tetap ingin berada pada rambu-rambu syariah, maka solusi tepat adalah modal ventura Syariah.

Keberadaan usaha modal ventura di Indonesia dalam arti institusional dan formal merupakan pranata hukum dan bisnis yang relatif masih baru. U saha ini baru diperkenalkan melalui Kebijaksanaan Paket Deregulasi tanggal 20 desember 1988 yang diikuti dngan dikeluarkannya Keppres No. 61 tahun 1988. Pada saat ini pengawasan, pembinaan, dan perizinan modal ventura dilakukan oleh Otoritas Jasa Keuangan (OJK) sebagaimana UU No.21 Tahun 2011 tentan Otoritas Jasa Keuangan (OJ K). Setelah berdirinya OJK paling tidak, OJK telah menerbitkan 4 (empat) peraturan tentang M odal V entura. K eempat POJK tersebut, di antaranya Peraturan Otoritas Jasa K euangan Nomor 35/POJ K.05/2015 Tentang Penyelenggaraan Usaha Perusahaan Modal Ventura, Peraturan Otoritas Jasa Keuangan Nomor 34/POJK.05/2015 Tentang Perizinan Usaha Dan Kelembagaan Perusahaan Modal V entura, Peraturan Otoritas J asa K euangan Nomor 37/POJK.05/2015 Tentang Pemeriksaan Langsung Perusahaan Modal Ventura, Peraturan Otoritas Jasa Keuangan Nomor 36/POJK.05/2015 Tentang Tata Kelola Perusahaan Yang Baik Bagi Perusahaan Modal V entura.

Di satu sisi, kehadiran modal ventura syariah tidak hanya semata-semata mengakomodasi kepentingan umat muslim saja, namun juga lebih mengedepankan pada faktor keunggulan dan manfaat dengan memberikan bantuan pembiayaan kepada kegiatan ekonomi baik kecil, menengah dan besar serta dengan adanya prinsip yang sesuai syariah. Modal ventura merupakan suatu bentuk pemberian modal kepada suatu perusahaan dalam bentuk penyertaan modal dimana dalam hal ini perusahaan modal ventura tidak mempersyaratkan adanya jaminan (agunan) seperti halnya dalam perbankan syariah. Untuk perusahaan yang hendak meminjam dari lembaga keuangan akan tetapi tidak ingin mendapatkan atau membayar bunga seperti halnya dalam perbankan konvensional, maka modal ventura syariah menjadi salah satu solusinya.

Modal ventura syariah beroperasi berdasarkan prinsip- prinsip syariah sehingga, perusahaan yang akan mengajukan pembiayaan tidak perlu merasa takut uang yang dipinjamnya itu ada unsur riba. A kan tetapi, keberadaan lembaga keuangan modal ventura syariah sampai saat ini masih jarang terdengar. Hal ini karena masih terbatasnya jumlah dan pembiayaan yang diberikan oleh perusahaan modal ventura. Sampai M aret 2016 berdasarkan data dari otoritas jasa keuangan, jumlah pembiayaan dari modal ventura syariah berjumlah Rp.380 miliar yang terdiri dari penyertaan saham Rp.0, Obligasi konversi Rp.0, pembiayaan bagi hasil (net) Rp.380 milyar, pembiayaan bagi hasil (bruto) Rp.383 milyar. A kumulasi penyisihan Rp.3 milyar. Jumlah tersebut masih jauh dibandingkan dengan jumlah pembiayaan/penyertaan modal ventura konvensional pada periode yang sama, berdasarkan data dari otoritas jasa keuangan, jumlah pembiayaan dari modal ventura konvensional 
berjumlah 7.439 miliar rupiah, dengan rincian penyertaan saham Rp. 1.415 milyar, obligasi konversi R p.481 milyar, pembiayaan bagi hasil (net) R p.5.543 milyar, Pembiayaan bagi hasil (bruto) Rp.5.683 milyar dan akumulasi penyisihan R p.139 milyar.

Dari perbedaan jumlah pembiayaan/penyertaan yang diberikan oleh perusahaan modal ventura konvensional dan jumlah pembiayaan/penyertaan yang diberikan oleh perusahaan modal ventura syariah jelas terlihat bahwa perusahaan modal ventura syariah belum terlalu diketahui oleh masyarakat, terutama untuk masyarakat muslim.

\section{Pengertian M odal V entura Syariah}

Istilah "ventura" berasal dari kata "venture" yang secara harfiah dapat berarti sesuatu yang mengandung risiko atau dapat pula diartikan dengan usaha. Dengan demikian, pengertian modal ventura atau venture capital secara sempit adalah modal yang ditanamkan pada usaha yang mengandung risiko, baik dalam bentuk penyertaan modal saham ${ }^{1}$, obligasi konversi (convertible bond) ${ }^{2}$ maupun pinjaman yang dapat dikonversi menjadi saham (convertible loan stock). ${ }^{3}$

M enurut Tony Lorenz, modal ventura adalah investasi jangka panjang dalam bentuk pemberian modal yang mengandung resiko di mana penyedia modal (venture capitalist) mengharapkan capital gain. ${ }^{4}$

The B ank of England Quarterly Buletin, memberikan pengertian bahwa modal ventura adalah suatu aktivitas dengan mana pihak investor mendukung bakat-bakat enterpeneur dengan skill finansial dan bisnis, untuk memanfaatkan pasar dan karenanya akan mendapatkan capital gains, ${ }^{5}$ yang bersifat long terms (venture capital as an activity, which whom yhe investors support entrepreneurs falent with financial skill and business to take an adventage from market and there fore, if will get a long term capital gains). ${ }^{6}$

Sedangkan menurut Peraturan Otoritas Jasa Keuangan Nomor 34/POJK.05/2015 Tentang Perizinan Usaha Dan Kelembagaan Perusahaan Modal Ventura adalah usaha pembiayaan melalui penyertaan modal dan atau pembiayaan untuk jangka waktu tertentu dalam rangka pengembangan usaha pasangan usaha atau debitur.

Dari beberapa pengertian di atas dapat disimpulkan modal ventura adalah usaha pembiayaan yang mengandung risiko, baik dalam bentuk penyertaan modal saham, obligasi konversi (convertible bond) maupun pinjaman yang dapat dikonversi menjadi saham

\footnotetext{
${ }^{1}$ M odal Saham adalah tanda penyertaan atau kepemilikan seseorang atau badan dalam suatu perusahaan atau perseroan terbatas. Wujud saham adalah selembar kertas yang menerangkan bahwa pemilik kertas tersebut adalah pemilik perusahaan yang menerbitkan surat berharga tersebut.

${ }_{2}^{2}$ Obligasi konversi atau yang dikenal juga dengan nama convertible bond, adalah suatu jenis obligasi yang dapat dikonversikan menjadi saham dari perusahaan penerbit obligasi dan biasanya pada rasio pertukaran yang sudah ditentukan terlebih dahulu pada penerbitan obligasi tersebut.

${ }^{3}$ Dahlan Siamat, M anajemen L embaga K euangan (J akarta: Intermedia, 1995), 189

${ }^{4}$ V eithzal Rivai, Bank dan Finance Institution M anagement (J akarta: PT .RajaG rafindo, 2007), 1141

${ }^{5} \mathrm{~K}$ euntungan M odal (Capital gain) adalah suatu keuntungan atau laba yang diperoleh dari investasi dalam surat berharga atau efek, seperti saham, obligasi atau dalam bidang properti, di mana nilainya melebihi harga pembelian.

${ }^{6}$ Liya Sukma Muliya, Perusahaan Modal Ventura Dalam Perspektif Hukum Bisnis Dan Hukum Islam (Bandung: Penerbit Fakultas Hukum Universitas Islam B andung, 2008), 12
} 
(convertible loan stock) dengan jangka waktu tertentu dalam rangka pengembangan usaha pasangan usaha atau debitur dimana penyedia modal (venture capitalist) mengharapkan capital gain.

Usaha modal ventura syariah menurut Peraturan Otoritas Jasa Keuangan Nomor 34/POJK.05/2015 Tentang Perizinan Usaha Dan Kelembagaan Perusahaan M odal Ventura adalah usaha pembiayaan melalui kegiatan investasi dan atau pelayanan jasa yang dilakukan dalam jangka waktu tertentu dalam rangka pengembangan usaha pasangan usaha yang dilaksanakan berdasarkan prinsip syariah. ${ }^{7}$

\section{K onsep M odal V entura Syariah}

Karakteristik yang sangat menonjol dalam usaha modal ventura adalah berkaitan dengan risiko. Besarnya risiko yang mungkin dihadapi dalam bisnis modal ventura ini menyebabkan tingginya expect return yang diharapkan oleh ventura capitalist. Konsep modal ventura pada dasarnya tidak dapat disamakan dengan penyertaan biasa dan tidak semua penyertaan modal pada perusahaan lain dapat digolongkan sebagai pembiayaan modal ventura.

Modal ventura pada prinsipnya merupakan suatu proses yang menggambarkan arus investasi yang dimulai dari masuknya pemodal dengan membentuk suatu pool of funds, proses pembiayaan pada Perusahaan Pasangan Usaha (PPU) sampai proses penarikan kembali penyertaan tersebut (diinvestasi).

Untuk gambarannya dapat dilihat pada tabel diagram di bawah ini :

\section{Diagram 1 \\ Konsep Dana V entura}

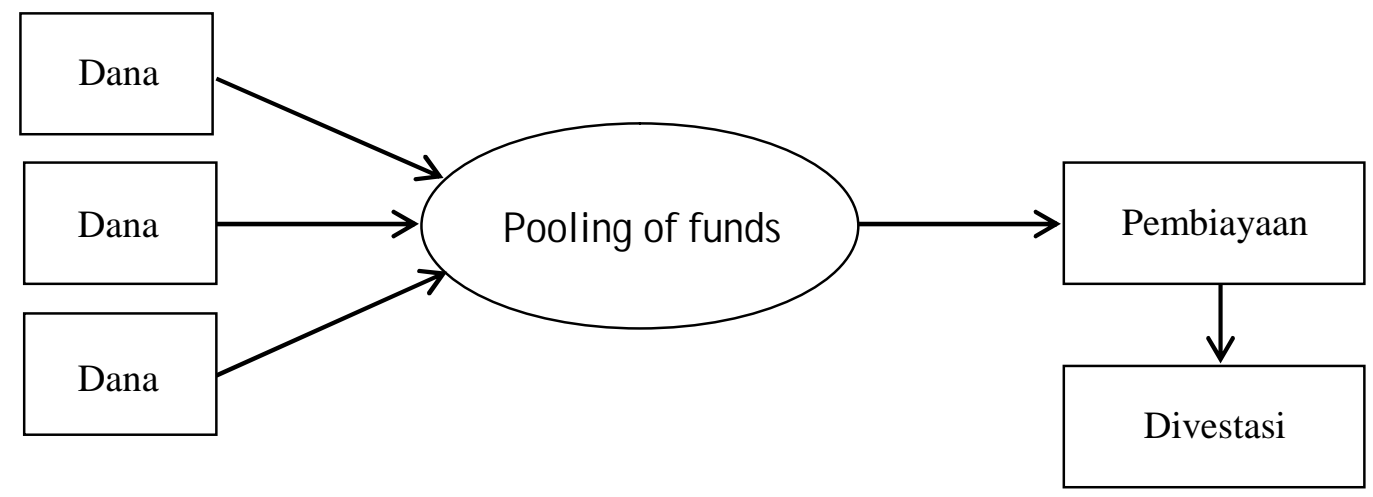

Sedangkan konsep modal ventura syariah berlandaskan konsep umum modal ventura dengan penekanan kepada prinsip-prinsip sebagai berikut :

1. Mekanisme pembiayaan dalam modal ventura dilakukan dalam bentuk penyertaan modal.

2. Metode pengambilan keuntungan dalam modal ventura dilakukan melalui bagi hasil atas keuntungan yang diperoleh kegiatan usaha yang dibiayai.

\footnotetext{
${ }^{7}$ Prinsip-prinsip syariah tidak melakukan perniagaan atas barang-barang yang haram, tidak menggunakan bunga (riba), tidak melakukan perjudian dan spekulasi yang disengaja (maisir), serta Ketidakjelasan dan manipulatif (gharar).
} 
3. Produk pembiayaan modal ventura dikeluarkan oleh lembaga keuangan bukan bank, yaitu perusahaan pembiayaan modal ventura.

4. Jaminan dalam pembiayaan modal ventura tidak diperlukan, karena sifat pembiayaannya lebih condong ke sebuah bentuk investasi.

5. Sumber dana untuk pembiayaan modal ventura bisa berasal dari perusahaan Modal V entura sendiri dan juga berasal dari pihak lain.

6. U paya penyelesaian apabila terjadi wanprestasi dalam pembiayaan modal ventura, baik yang dilakukan oleh perusahaan modal ventura maupun perusahaan pasangan usaha, maka upaya penyelesaiaannya dapat dilakukan melalui upaya damai, pengadilan negeri, dan lembaga arbitrase. ${ }^{8}$

7. Pengembangan usaha pasangan usaha yang dilaksanakan berdasarkan prinsip syariah.

\section{Karakteristik M odal V entura Syariah}

Modal ventura di Indonesia dalam menjalankan kegiatannya memberikan fasilitas pembiayaan dan pendampingan manajemen pada perusahaan pasangan usaha (PPU) ke dalam perusahaan yang dibiayainya. Pola pembiayaan perusahaan dilakukan dengan mengadopsi teknik investasi yang dilakukan oleh A merican Research and Development Corporation (ARDC).

K arakteristik modal ventura sebagai berikut: ${ }^{9}$

1. Pemberi bantuan finansial dalam bentuk modal ventura ini tidak hanya menginvestasikan modalnya saja. T etapi juga ikut terlibat dalam manajemen perusahaan yang dibentuknya.

2. Investasi yang dilakukan tidaklah bersifat permanen, tetapi hanyalah bersifat sementara, untuk kemudian sampai masanya dilakukanlah investasi.

3. Motif dari modal ventura adalah motif bisnis yaitu mendapatkan keuntungan setinggitingginya, walaupun dengan risiko yang relatif tinggi pula.

4. Investasi dengan bentuk modal ventura yang dilakukan ke perusahaan pasangan usahanya bukan investasi jangka pendek, tetapi merupakan investasi jangka menengah atau jangka panjang.

5. Modal ventura merupakan investasi tanpa jaminan collateral sehingga dibutuhkan kehati-hatian dan kesabaran.

6. Investasi tersebut bukan bersifat pembiayaan dalam bentuk pinjaman, tetapi dalam bentuk partisipasi equity, atau setidaknya loan yang dapat dilakukan ke equity. Sehingga return yang diharapkan oleh perusahaan modal ventura bukanlah bunga atas modal yang ditanam, melainkan deviden dan capital gain.

\footnotetext{
${ }^{8}$ B adan A rbitrase Nasional Indonesia atau BA NI adalah suatu badan yang dibentuk oleh pemerintah Indonesia guna penegakan hukum di Indonesia dalam penyelesaian sengketa atau beda pendapat yang terjadi diberbagai sektor perdagangan, industri dan keuangan, melalui arbitrase dan bentuk-bentuk alternatif penyelesaian sengketa lainnya antara lain di bidang-bidang korporasi, asuransi, lembaga keuangan, pabrikasi, hak kekayaan intelektual, lisensi, waralaba, konstruksi, pelayaran/maritim, lingkungan hidup, penginderaan jarak jauh, dan lain-lain dalam lingkup peraturan perundang-undangan dan kebiasaan internasional.

${ }_{9}$ M unir Fuady, Hukum tentang pembiayaan dalam teori dan praktek (leasing, factoring, modal ventura, pembiayaan konsumen, kartu kredit) (Bandung: PT. Citra A ditya Bakti, 1999), 110-112
} 
7. Prototype dari pembiayaan dengan modal ventura adalah pembiayaan yang ditujukan kepada perusahaan kecil atau perusahaan baru, tetapi memiliki potensi untuk berkembang.

8. Investasi modal ventura biasanya dilakukan terhadap perusahaan yang tidak punya akses untuk mendapatkan kredit perbankan.

Untuk mendapatkan gambaran lebih jelas karateristik usaha modal ventura, dapat dilihat pada tabel di bawah ini perbandingan antara usaha modal ventura dengan pembiayaan/kredit perbankan.

Tabel $1^{10}$

Perbandingan antara M odel V entura dengan K redit Perbankan

\begin{tabular}{|c|c|c|}
\hline K eterangan & M odal V entura & K redit Perbankan \\
\hline T ujuan Investasi & $\begin{array}{l}\text { M emaksimalkan capital } \\
\text { gain }\end{array}$ & M emperoleh bunga \\
\hline Jangka waktu & $\begin{array}{l}\text { Jangka panjang (maksimal } \\
10 \\
\text { tahun) }\end{array}$ & $\begin{array}{l}\text { Jangka pendek, } \\
\text { menengah dan panjang }\end{array}$ \\
\hline Instrumen & $\begin{array}{l}\text { Saham biasa, obligasi } \\
\text { konversi, options, warrants }\end{array}$ & Pinjaman \\
\hline Tarif & $\begin{array}{l}\text { Price earning ratio net } \\
\text { tangible assets }\end{array}$ & Suku bunga \\
\hline Jaminan & Tidak ada & Ada \\
\hline Kepemilikan & Ada & Tidak ada \\
\hline Pengendalian & $\begin{array}{l}\text { Monitor } \\
\text { y stakeholder } \\
\text { right } \\
\text { protection }\end{array}$ & Covenants \\
\hline Dampak pada neraca & M engurangi laverage & M eningkatkan laverage \\
\hline Dampak pada cashflow & M eningkat & M eningkat \\
\hline Dampak pada laba & M eningkat & M eningkat \\
\hline M ekanisme divestasi & $\begin{array}{l}\text { IPO Sale to third party, } \\
\text { sale entrepenuer, } \\
\text { private placement }\end{array}$ & Pelunasan utang \\
\hline
\end{tabular}

\section{M ekanisme K erja M odal V entura}

Konsep modal ventura adalah proses arus investasi yang dimulai dari masuknya pemodal dengan membentuk suatu pool of funds, proses pembiayaan pada Perusahaan Pasangan Usaha (PPU) sampai proses penarikan kembali penyertaan tersebut (di investasi). Dari konsep ini dapat dibuat mekanisme kerja modal ventura. A da dua mekanisme kerja yang umum berkembang di berbagai negara di dunia, yaitu :

\footnotetext{
${ }^{10}$ V eithzal Rivai, B ank dan Finance Institution M anagement, 1155
} 
1. Single tier approach, yaitu modal ventura yang dikelola oleh Manajemen PM V yang membentuk/mendirikan perusahaan tersebut atau disebut. ${ }^{11} \mathrm{Di}$ dalam single tier apparoach paling sedikit ada tiga unsur yang terlibat secara langsung, yaitu:

a. Pemilikan modal yang menginginkan keuntungan yang tinggi dari modal yang dimilikinya. Modal dari berbagai sumber atau investor tersebut dihimpun dalam suatu wadah atau lembaga khusus yang dibentuk untuk itu atau disebut ventura capital funds.

b. Profesional yang mempunyai keahlian dalam mengolah investasi potensial. Profesional ini dapat berupa lembaga yang disebut management ventura fund company.

c. Perusahaan yang membutuhkan modal untuk pengembangan usahanya. Perusahaan yang dibiayai ini disebut investee company atau perusahaan pasangan usaha (PPU). ${ }^{12}$

Diagram 2

Single Tier A pparoach

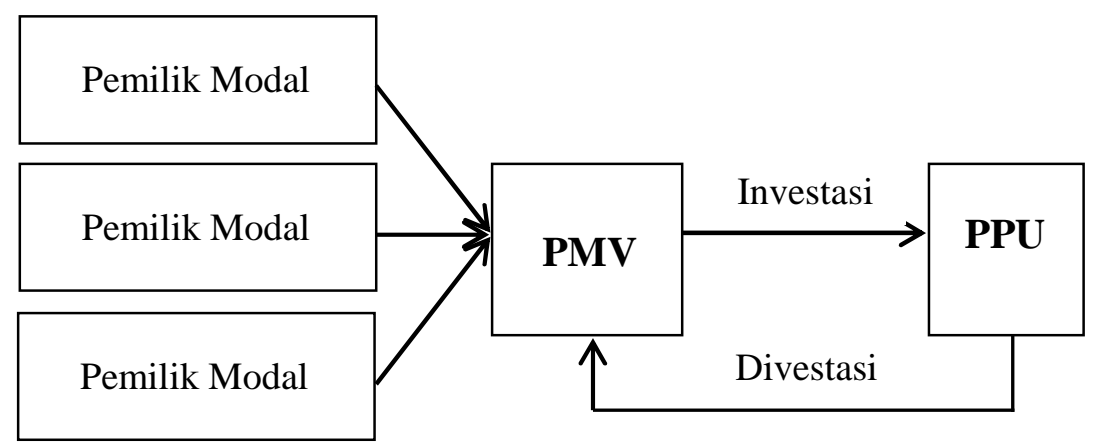

2. Model two tier approach yaitu modal ventura yang pengelolanya diserahkan pada perusahaan manajemen investasi yang professional. ${ }^{13}$

Modal ventura yang dikelola oleha Manajemen PMV yang membentuk/mendirikan perusahaan tersebut atau disebut single tier approach. ${ }^{14} \mathrm{Di}$ dalam single tier apparoach paling sedikit ada empat unsur yang terlibat secara langsung, yaitu:

a. Pemilikan modal yang menginginkan keuntungan yang tinggi dari modal yang dimilikinya. Modal dari berbagai sumber atau investor tersebut dihimpun dalam suatu wadah atau lembaga khusus yang dibentuk untuk itu atau disebut ventura capital funds.

b. Profesional yang mempunyai keahlian dalam mengolah investasi potensial. Profesional ini dapat berupa lembaga yang disebut management ventura fund company.

c. Profesional yang mempunyai keahlian dalam mengolah investasi potensial. Profesional ini dapat berupa lembaga yang disebut management company. Lembaga ini dari kegiatannya mendapatkan management fee dan succes fee yang dibayar oleh PM V atas

\footnotetext{
${ }^{11}$ |bid., 1143

12 Frianto Pandia, L embaga K euangan (J akarta: Rineka Cipta, 2005), 88

${ }^{13} \mathrm{~V}$ eithzal Rivai, B ank dan Finance Institution M anagement, 1143

${ }^{14}$ A ndi Soemitra, Bank dan L embaga K euangan Syariah (J akarta: K encana Prenada M edia Group, 2012), 320
} 
fasilitasi kepada PPU. Fasilitasi yang diberikan oleh management company kepada PPU berupa Indentifikasi, evaluasi, monitoring, administrasi, dan mengkaji.

d. Perusahaan yang membutuhkan modal untuk pengembangan usahanya. Perusahaan yang dibiayai ini disebut investee company atau perusahaan pasangan usaha (PPU).

Diagram 3

Two Tier A pparoach

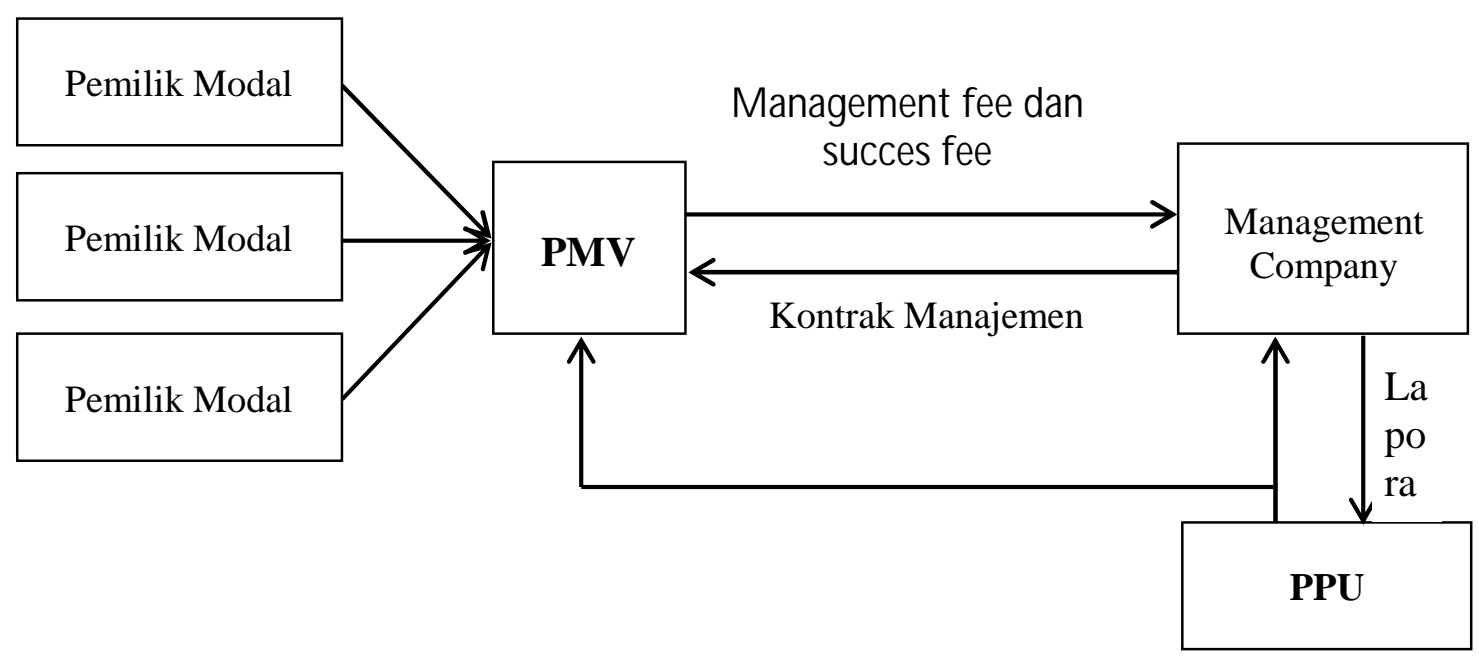

\section{Sumber Dana M odal V entura Syariah}

Sumber modal ventura dapat berasal dari perorangan, saham, obligasi konversi, bagi hasil, investor institusi, perbankan, pemerintah daerah maupun lembaga internasional. ${ }^{15}$

\section{D asar Hukum M odal V entura Syariah}

Landasan hukum pelaksanaan usaha modal ventura sangat berkembang mengikuti perubahan-perubahan organisasi/kelembagaan yang terkait dengan sektor moneter dan keuangan.

A dapun beberapa landasan hukum untuk menjalankan usaha modal ventura, sebagai berikut : 16

1. Peraturan Otoritas Jasa K euangan Nomor 35/POJK.05/2015 Tentang Penyelenggaraan U saha Perusahaan M odal V entura.

2. Peraturan Otoritas Jasa K euangan Nomor 34/POJK.05/2015 Tentang Perizinan U saha Dan K el embagaan Perusahaan M odal V entura.

3. Peraturan Otoritas Jasa Keuangan Nomor 37/POJK.05/2015 Tentang Pemeriksaan L angsung Perusahaan M odal V entura.

4. Peraturan Otoritas Jasa Keuangan Nomor 36/POJK.05/2015 Tentang Tata Kelola Perusahaan $Y$ ang Baik Bagi Perusahaan M odal V entura.

\section{Pembiayaan M odal V entura Syariah}

1. A kad-akad syariah dalam pembiayaan modal ventura

15 V eithzal Rivai, B ank dan Finance ....., 1148-1150

${ }^{16}$ Liya Sukma M uliya, Perusahaan M odal V entura ... ., 22-28 
Pembiayaan modal ventura berdasarkan akad syariah terbagi menjadi (tiga) yaitu :17

a. M usyarakah mencampurkan dana untuk mendirikan usaha baru atau kontrak proyek dengan tujuan memperoleh keuntungan. Pemilik modal dalam musyarakah ini adalah dua pihak atau lebih (misalnya ventura capital company, pengusaha, dan silent patner). Keuntungan atau kerugian usaha atau kontrak proyek dinikmati atau ditanggung bersama-sama sesuai dengan porsi atau profit/loss sharing yang ditetapkan dalam kesepakatan/perjanjian awal.

Dalam pembiayaan syariah musyarakah mempunyai implementasi spesifik dalam bentuk saham.

Prinsip-prinsip saham secara syariah adalah :

1) Bersifat musyarakah jika saham ditawarkan secara private.

2) Bersifat mudharabah jika saham ditawarkan secara publik.

3) Tidak boleh ada perbedaan jenis saham karena resiko harus ditanggung oleh semua pihak.

4) Seluruh keuntungan akan dibagi hasil dan jika terjadi kerugian akan dibagi rugi setelah dilikuidasi.

5) Investasi pada saham tidak dapat dicairkan dari usaha atau proyek yang bersangkutan kecuali dalam keadaan bangkrut atau dialihkan lewat jual beli investasi.

b. Mudharabah untuk pembiayaan usaha atau proyek dapat disejajarkan dengan instrumen pembiayaan obligasi/quasi seperti obligasi konversi. Perusahaan merupakan pemegang amanah terhadap modal yang diterima dari pemilik modal (ventura capital company) dimana modal merupakan titipan/amanah dalam konsep wadiah yang dapat dimanfaatkan untuk memperoleh keuntungan. Pengusaha saat melakukan proyek yang berkaitan dengan mudharabah adalah wakil pemilik modal. J ika pengusaha memperoleh keuntungan, pengusaha bertindak sebagai mitra pemilik modal. Dengan demikian, keuntungan tersebut harus dibagikan sesuai dengan prinsip musyarakah yang mengharuskan adanya bagi hasil yang adil antara mitra perkongsian.

Modal disediakan seluruhnya oleh pemilik modal sampai suatu masa tertentu dimana modal tersebut dikembalikan secara utuh.

Mudharabah ini sering disebut trust financing yang hanya diberikan kepada pengusaha yang sudah teruji memegang amanah dengan baik. Jika terjadi satu lain hal yang merugikan kedua belah pihak, hal itu tidak disebabkan oleh kesalahan pengelola si pengusaha sehingga resiko dapat ditanggung secara adil.

Dalam pembiayaan syariah mudharabah mempunyai implementasi spesifik dalam bentuk quasi equity, seperti obligasi konversi.

Prinsip dasar operasi obligasi secara syariah adalah :

1) Bersifat mudharabah (namun tidak harus menanggung rugi) atau muqaradah.

2) U mumnya mendapatkan pembagian dari pendapatan (revenue sharing).

${ }^{17}$ V eithzal Rivai, B ank dan Finance ....., 1175-1177 
3) Dapat dijual di bawah nilai pari kalau perusahaan mengalami kerugian jika terbentuk mekanisme pasar modal syariah.

4) Perubahan nilai pasar bukan berarti perubahan jumlah utang.

Sementara itu prinsip dasar quasi secara syariah adalah :

1) Bersifat mudharabah.

2) Penyertaan tidak sepanjang umum perusahaan (hanya sepanjang umum proyek spesifik).

3) Seluruh keuntungan dan kerugian akan dibagi secara kontrak.

4) Nilai penyertaan dapat menurun.

5) Komitmen sama seperti penyertaan modal tetap.

c. Murabahah untuk jual beli barang investasi atau bahan baku dimodal kerja (merupakan konsep penyerdahanaan instrumen bagi hasil ke jual beli dengan resiko penanganan pembayaran dan fluktuasi harga).

M urabahah adalah jual beli barang pada harga asal dengan tambahan keuntungan yang disepakati. Karateristiknya adalah penjual harus memberitahu harga produk yang ia beli dan menentukan suatu tingkat keuntungan sebagai tambahannya. $M$ isalnya pihak ventura capital company bernegosiasi dengan entitas usaha yang ingin membeli barang investasi dalam bentuk mesin. Maka, entitas usaha tersebut memesan pada ventura capital company. Untuk membeli mesin dari produsen dengan kesepakatan atau perjanjian bahwa entitas usaha akan membeli mesin tersebut dari venture capital company setelah mesin tersebut dimiliki oleh venture capital company dengan harga dan keuntungan yang pantas dengan memperhitungkan resiko penanggungan pembayaran dan fluktuasi harga. Perhitugan resiko penanggungan pembayaran dan fluktuasi harga dilakukan karena adanya tenggang waktu antara pengadaan dan pelunasan mesin yang dibiayai venture capital company. Instrumen pembiayaan ini jika dibuat revolving, dapat juga diaplikasikan untuk pengadaan pupuk bagi pertanian ataupun bahan baku tertentu bagi pabrik.

Pada skema pembiayaan murabahah terdapat 2 (dua), yaitu :

1) Salam untuk jual beli dibayar di depan untuk produk-produk pertanian, terindentifikasi dengan jelas bentuk, ukuran, kualitas, dan kuantitasnya (merupakan konsep penyederhaaan instrumen bagi hasil ke jual beli dengan resiko penangguhan pembayaran dan fluktuasi harga).

Salam adalah proses jual beli yang pembayarannnya dilakukan secara advance manakala penyerahan barang dilakukan kemudian. Penekanannya adalah bahwa pembayaran di muka ini harus diikuti dengan spesifikasi produk pertanian yang mutu (grade) secara jumlah (berat) sesuai dengan kesepakatan atau perjanjian.

2) Skema pembayaran salam pararel (Pola inti plasma) masih banyak pembiayaan syariah yang dapat diimplementasikan dalam venture capital yang dapat dikembangkan menjadi cikal bakal pasar modal syariah. Pasar modal syariah sendiri akan terbangun dan terbentuk dengan kebiasaan komunitas keuangan dalam menggunakan dan menerapkan peroduk pembiayaan syariah. M engacu 
pada pembentukan pasar modal konvensional, maka pembentukan pasar modal syariah membutuhkan perangkat-perangkat.

2. Jenis U saha M odal V entura Syariah

J enis usaha modal ventura menurut secara umum dibagi menjadi tiga, yaitu :

a. Investasi

Investasi modal ventura syariah terdiri dari:

1) Penyertaan modal langsung (equity Financing) adalah penyertaan modal perusahaan modal ventura (PMV) pada perusahaan pasangan dengan cara mengambil bagian sejumlah tertentu saham perusahaan pasangan usaha (PPU).

2) Pembelian sukuk atau obliasi syariah konversi. ${ }^{18}$

3) Pembelian sukuk atau obligasi syariah yang diterbitkan pasangan usaha pada tahap rintisan awal (start up) dan/atau pengembangan usaha.

b. Pembiayaan berdasarkan prinsip bagi hasil

Instrumen pembiayaan ini dilakukan dalam hal usaha yang akan dibiayai tidak berbentuk badan hukum atau syarat-syarat yang harus dipenuhi untuk penyertaan langsung belum atau belum dipenuhi oleh PPU. Untuk instrumen pembiayaan ini menekankan pada aspek-aspek bagi hasil dari keuntungan yang diperoleh dari usaha dibiayai, oleh karena itu hal-hal yang perlu diperhatikan dalam bentuk pembiayaan ini adalah kewenangan bertindak pihak yang mewakili PPU, objek usaha serta jaminan atas pemberian bantuan dana.

Pembiayaan bagi hasil ini lebih banyak diserap oleh UMKM dengan akad musyarakah atau mudharabah.

c. Pelayanan jasa

d. K egiatan usaha lain berdasarkan persetujuan 0JK

3. Pola pembiayaan modal ventura dan penerapannya dalam akad syariah.

Secara umum modal ventura terdapat 5 (Iima) bentuk/pola pembiayaan yaitu: ${ }^{19}$

a. Pola Pembiayaan L angsung

Pola pembiayaan ini dapat dilakukan oleh perusahaan modal ventura dengan cara emberikan pembiayaan langsung kepada perusahaan pasangan usaha yang sudah/akan berbentuk badan hukum. Apabila konsep ini dilakukan, maka perusahaan modal ventura harus berperan aktif langsung ke perusahaan pasangan usaha dan biasanya akan menempatkan wakilnya sebagai anggota direksi maupun komisaris.

Pola pembiayaan ini dapat dilakukan dengan 2 cara, yaitu mendirikan perusahaan baru dengan pemegang saham ${ }^{20}$ perusahaan modal ventura dan penemu/penggagas ide atau perusahaan modal ventura ikut menjadi pemegang saham perusahaan

18 Penyertaan modal tidak langsung melalui konversi ini didasarkan pada Fatwa DSN MUI No. 59/DSNM UI/v/2007 tentan Obligasi syariah M udharabah K onversi

${ }^{19}$ A ndi Soemitra, B ank dan Lembaga K euangan Syariah, 326-327

${ }^{20}$ Saham dalam pasar modal syariah merupakan suatu bukti penyertaan modal dalam suatu perusahaan sampai perusahaan ditutup atau dilikuidasi. Didasarkan pula pada fatwa DSN No.20/DSN-MUI/IV/2001 tentang Pedoman Pelaksanaan Investasi untuk Reksa Dana dan Fatwa N 0.40/DSN -M UI/IV /2003 tentang Pasar M odal dan Pedoman U mum Penerapan Prinsip Syariah di Bidang Pasar M odal 
pasangan usaha yang sudah ada dengan mengambil porsi modal yang masih dalam portofolio. Komposisi jumlah modal yang disetor oleh masing-masing pihak biasanya sudah ditentukan pada awal kontrak modal ventura dilakukan, dapat saja perusahaan modal ventura sebagai mayoritas ataupun sebaliknya.

K onsep pembiayaan langsung harus didukung dengan jumlah sumber daya manusia yang cukup banyak dan handal, tanpa hal ini, konsep ini banyak akan gagal. Untuk itu, perusahaan modal ventura biasanya akan melakukan kerja sama dengan jasa profesional dan lembaga/institusi tertentu untuk melakukan pengawasan.

Pembiayaan langsung menggunakan akad musyarakah. PMV/D bersama-sama dengan PPU menyediakan modal.

\section{Diagram $4^{21}$}

M odal V entura dengan Pembiayaan L angsung
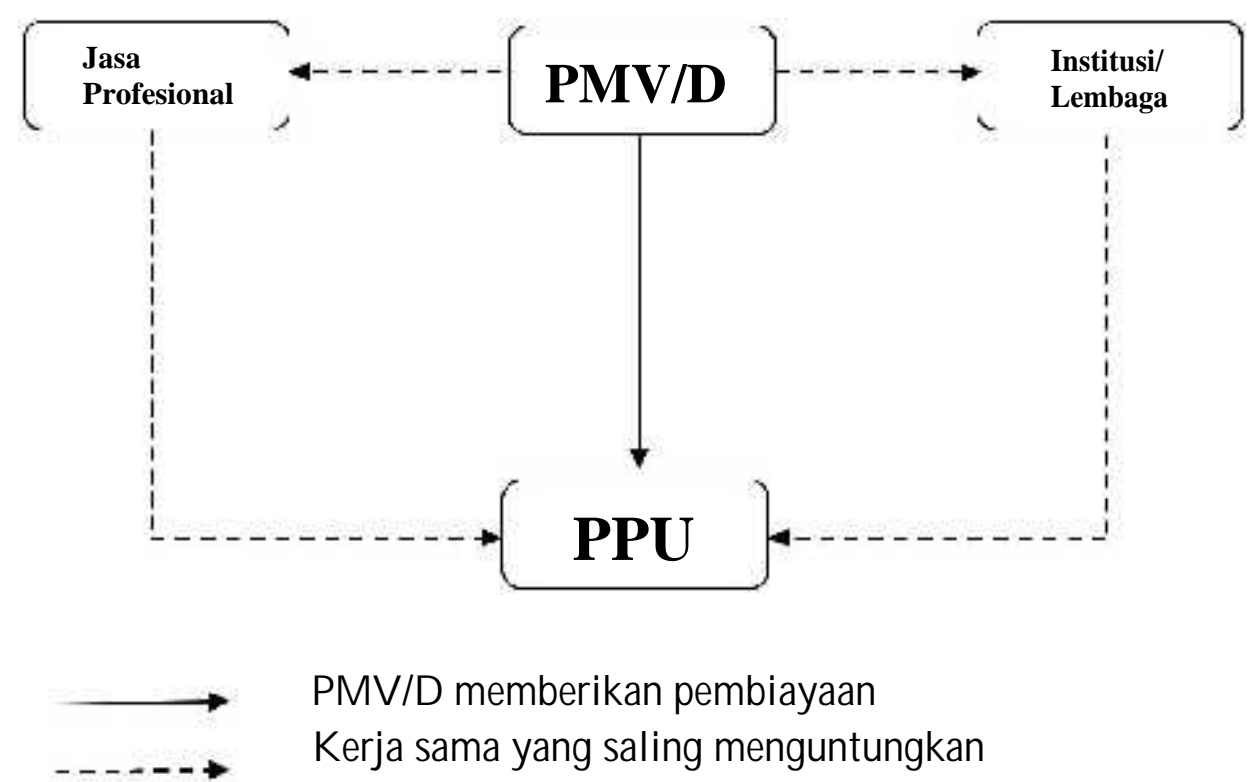

Pola kerja sama ini adalah pola pembiayaan langsung dari MV/D terhadap satu perusahaan atau individu. Calon perusahaan pasangan usaha dapat berbentuk CV, Firma, UD, usaha perseorangan ataupun sebuah perseroan terbatas. PM V /D berkerja sama dengan pihak ketiga untuk membantu memberikan jasanya (audit, pelatihan, hukum).

b. Pola Pembiayaan L angsung dengan Franchise

Pola pembiayaan langsung dengan franchise hampir sama dengan pola pembiayaan langsung, yang membedakannya adalah aktivitas pengawasan, pengontrolan yang diemban oleh perusahaan modal ventura ataupun jasa profesional dapat dialihkan kepada franchise. Dalam pola ini, perusahaan modal ventura terkesan lebih bersifat sebagai penyedia dana/modal kepada perusahaan pasangan usaha. Sistem franchise akan sangat membantu perusahaan modal ventura, terutama dalam membantu perusahaan pasangan usaha di dalam melakukan :

${ }^{21}$ V eithzal Rivai, B ank dan Finance ....., 1161 

1) Standar operasional
2) Bantuan teknis dan manajemen
3) Pengawasan mutu
4) Pelatihan

U ntuk itu, biasanya franchisor akan mendapatkan fee dari perusahaan modal ventura dan tetap mendapatkan royalty dari perusahaan pasangan usaha. Akad yang digunakan dalam pola pembiayaan langsung dengan franchise akad musyarakah.

Diagram 5

Pola Pembiayaan Langsung dengan Franchise

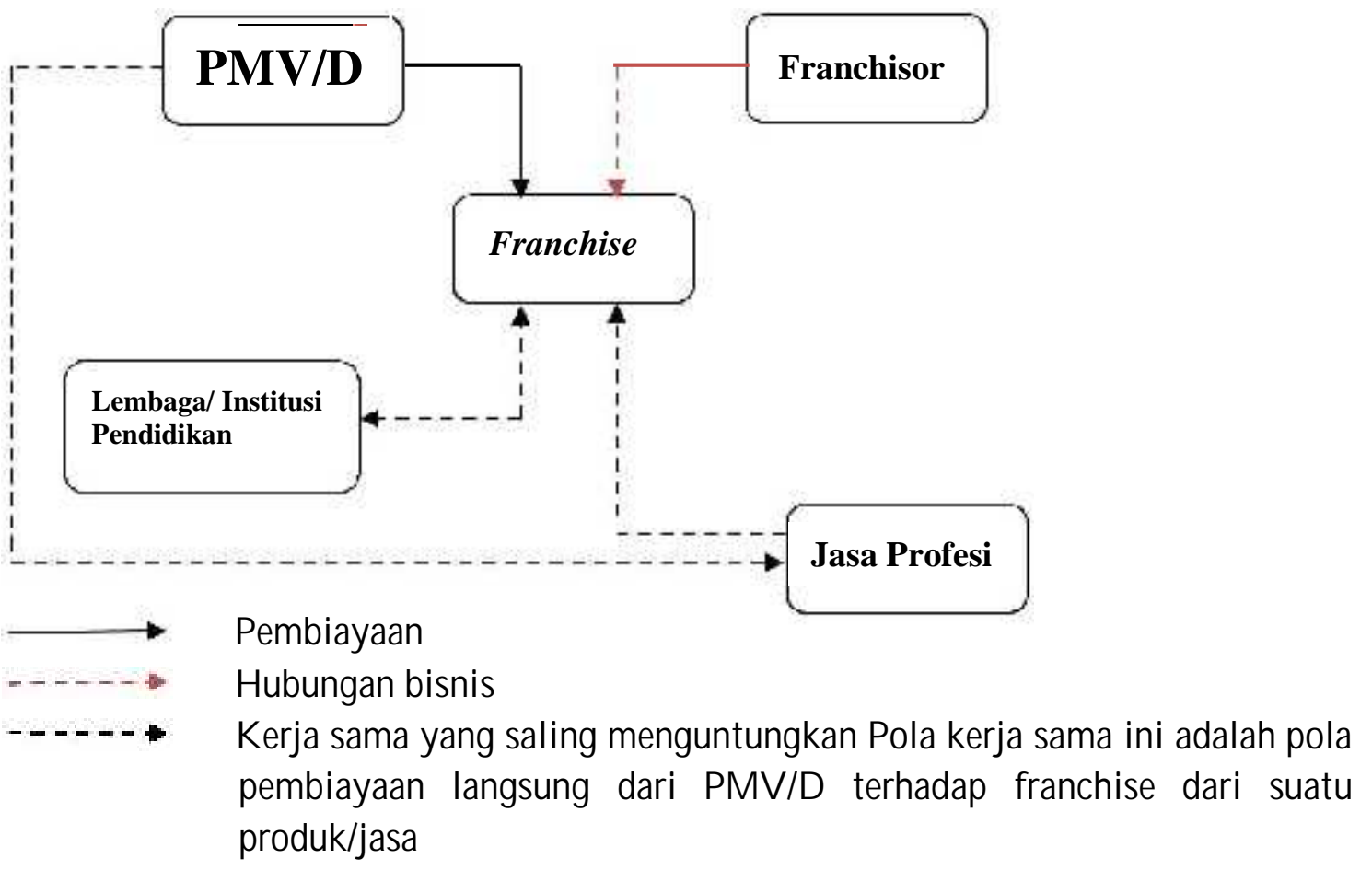

Franchise memperoleh bantuan teknis dan manajemen dari franchisor, dan untuk franchisor itu memperoleh fee. PMV/D bekerja sama dengan pihak ketiga untuk membantu memberikan jasanya (audit, pelatihan, hukum).

c. Pola Inti-Plasma

Pola inti-plasma hampir sama dengan pola pembiayaan langsung dengan franchise, yang membedakannya adalah jika memakai pola franchise, franchisor hanya melakukan bantuan teknis kepada satu satuan usaha saja. Sedangkan dengan pola inti-plasma, perusahaan inti akan membina beberapa perusahaan plasma dalam satu wadah usaha, dimana usaha setiap perusahaan plasma harus mendukung usaha perusahaan inti.

Dengan cara ini, diharapkan terjadi kesinambungan yang saling menguntungkan antara inti dan plasma. Pola inti-plasma sangat cocok dengan usaha yang bergerak di bidang perkebunan, penggemukan sapi, pertanian, transportasi ataupun warung sembilan bahan pokok. Pada skema Pola Inti Plasma akad yang digunakan salam. 
Diagram 6

Pola Inti-Plasma

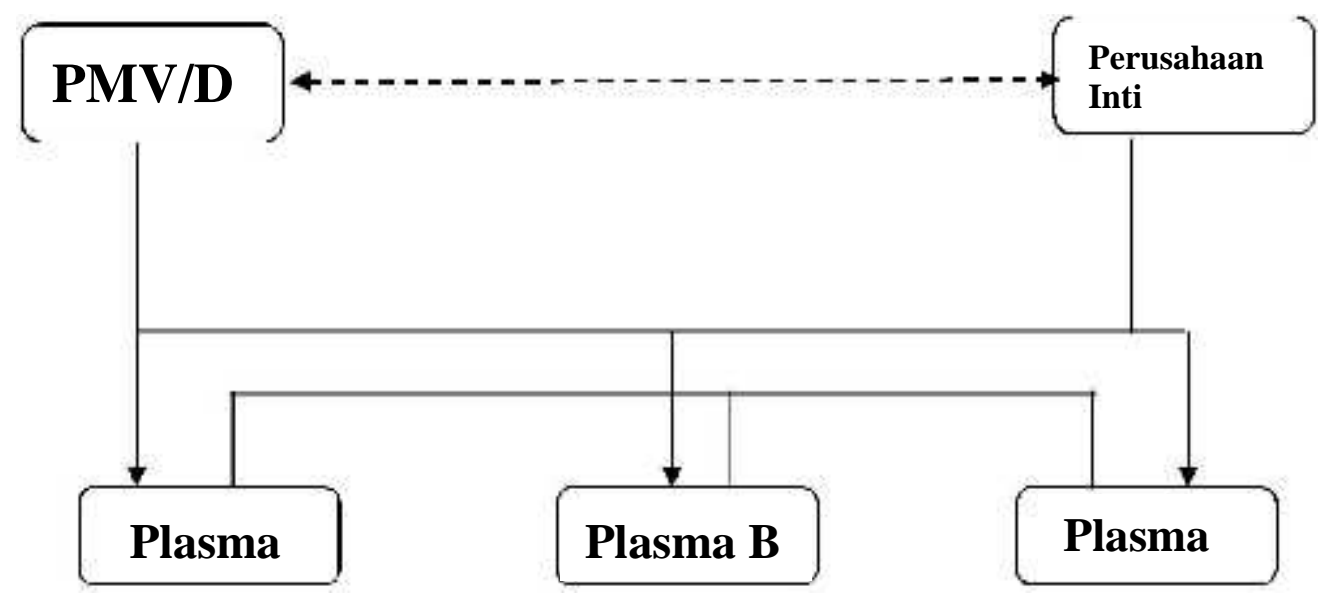

PM V /D memberikan pembiayaan Perusahaan inti mengkoordinasi para plasma

$\longleftrightarrow$ PM V/D dengan inti membentuk kerja sama yang saling menguntungkan

\section{d. Pola Payung}

Pola pembiayaan ini adalah suatu bentuk pembiayaan yang diberikan kepada suatu perusahaan yang kepemilikannya dipunyai oleh beberapa pemilik, dimana masingmasing pemilik mempunyai usaha yang saling menunjang satu sama lainnya sehingga nilai lebih yang didapat menjadi lebih baik.

Perusahaan yang didirikan ini berfungsi sebagai trading house bagi perusahaan para pemiliknya dan biasanya dikelola oleh tenaga professional yang tidak mempunyai hubungan dengan pemilik perusahaan, sehingga independensi terjaga dengan baik.

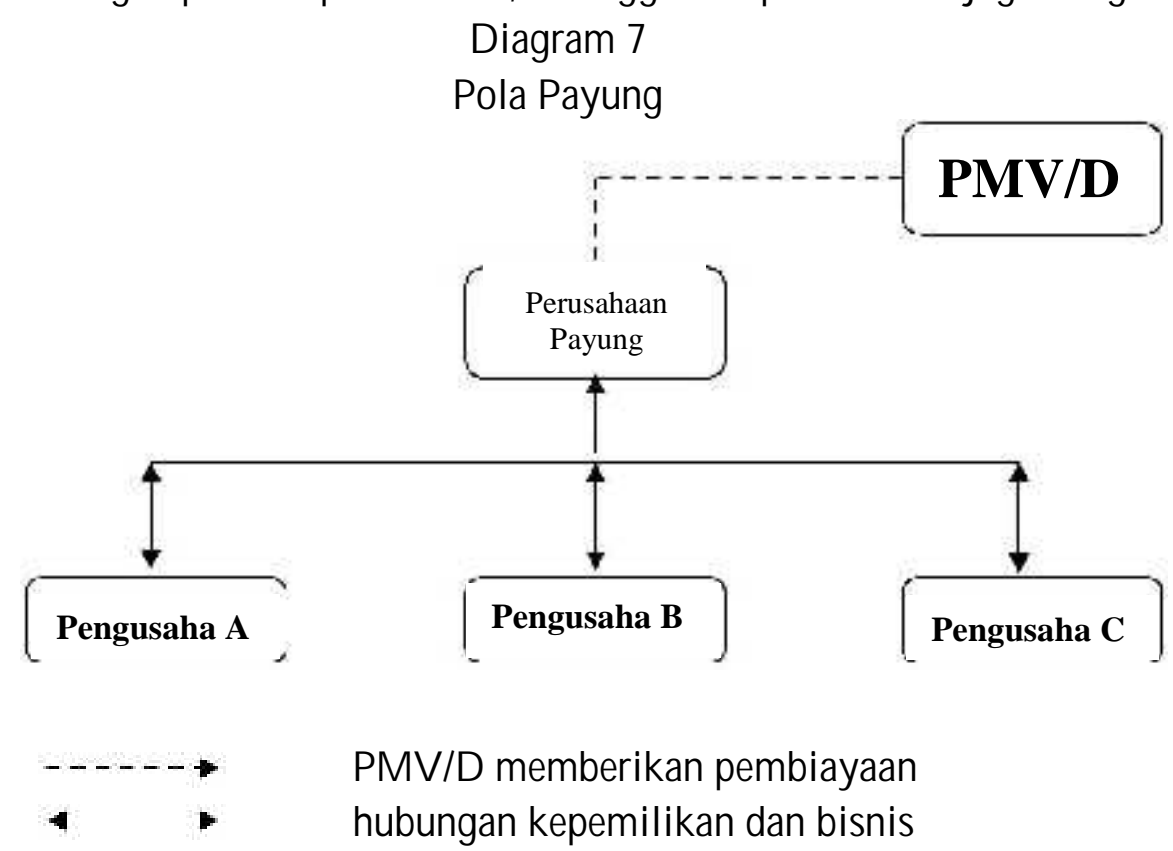


Pola kerja sama ini adalah pola pembiayaan kepada para pengusaha atau petani sejenis dengan membentuk perusahaan paying (kelompok). Perusahaan paying tersebut dimiliki oleh para pengusaha/petani sejenis bersama PMV/D dan/atau pengusaha yang sudah memiliki jaringan.

Perusahaan paying tersebut dikelola oleh para profesional yang bukan bagian dari pemilik. Dengan demikian, pengelolaan usaha tersebut lepas dari kepentingankepentingan individu para pengusaha/petani.

Perusahaan payung tersebut dapat berfungsi sebagai trading house, pemroses lanjutan untuk mendapatkan nilai tambah produk, membeli bahan baku agar bahanbahan yang diperoleh seragam, pengemasan, memberikan bantuan teknik, manajemen, dan lain-lain.

$M$ anfaat terbesar yang dapat diperoleh dari para pengusaha/petani tersebut adalah menigkatnya daya saing mereka terhadap para pembeli, pesaing, supplier, serta memberi nilai tambah atas produk yang dihasilkannya.

e. Pola K emitraan

Pola pembiayaan modal ventura dengan cara kemitraan harus melibatkan suatu perusahaan besar, yang akan membeli produk barang dan jasa yang dihasilkan dari perusahaan-perusahaan mitra binaan modal ventura. Pola kerja sama didahului dengan kerja sama antara perusahaan besar dengan perusahaan modal ventura, selanjutnya perusahaan modal ventura melakukan pembiayaan kepada perusahaan pasangan usaha ataupun sebaliknya.

A dapun tujuan dari pola kemitraan ini dimaksudkan untuk membantu dan membina secara bersama-sama demi kemajuan pemasok/supplier yang pada gilirannya akan memberikan nilai tambah bagi pengusaha besar. Di lain sisi, bagi para pemasok/supplier, jalinan kerja sama ini akan memberikan jaminan pasaran barang dan jasa yang dihasilkan dan terjadi hubungan timbal balik yang menguntungkan.

Diagram 8

Pola Kemitraan

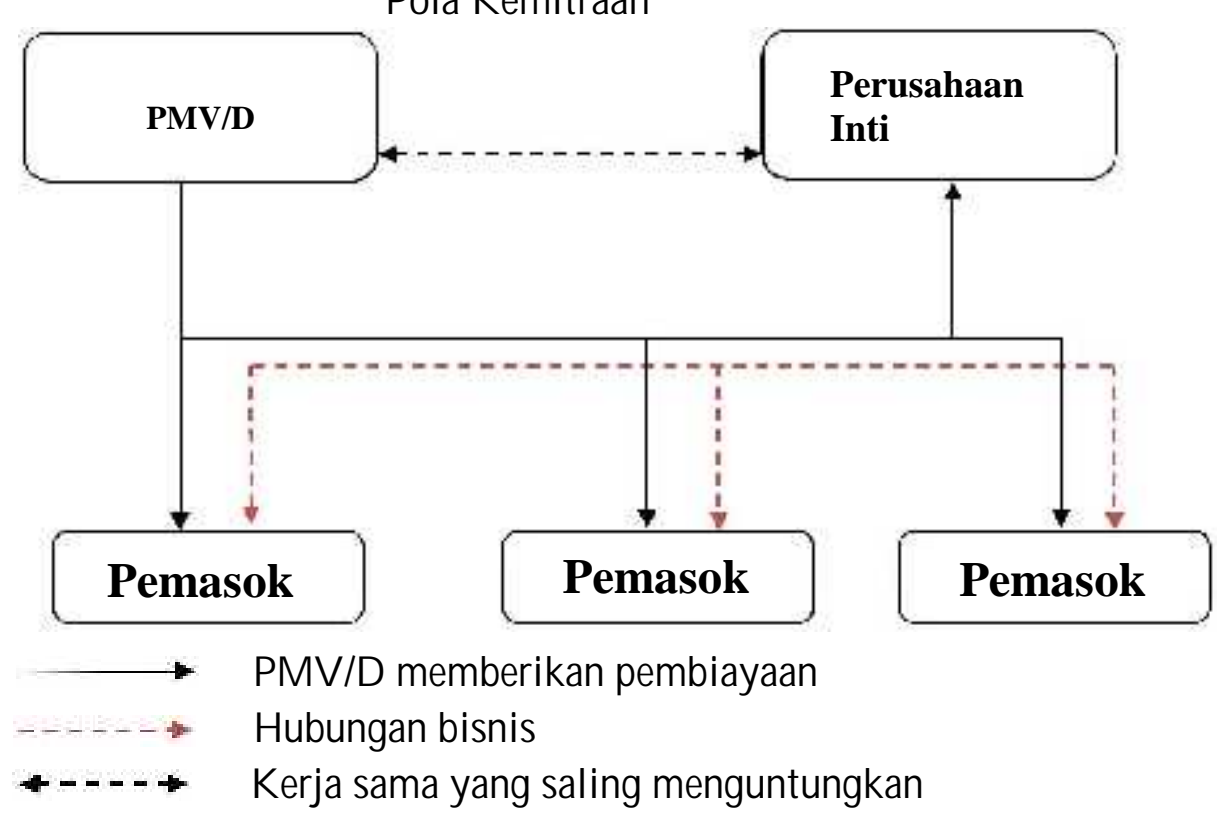


Pola kerja sama ini adalah pola pembiayaan kepada para pemasok atau supplier yang melibatkan pengusaha besar.

K erja sama antara PM V/D dengan pengusaha besar dimaksudkan untuk membantu dan membina secara bersama- sama demi kemajuan para pemasok/supplier yang pada gilirannya akan memberikan nilai tambah bagi pengusaha besar itu sendiri.

Dalam kerja sama yang dibina, diharapkan pengusaha besar bertindak sebagai penjamin pasar, manajemen mutu dari produksi yang dihasilkan oleh para pemasok/supplier.

\section{T ujuan dan M anfaat M odal V entura}

U saha modal ventura bertujuan untuk :22

1. Menumbuhkan dan mengembangkan kemampuan usaha dari pengusaha kecil dan menengah dengan mengusahakan segala bantuan yang diperlukan untuk mencapainya, tanpa mengabaikan kaidah berusaha yang sehat;

2. Membantu kelancaran pertumbuhan usaha kecil dan menengah dengan jalan mengadakan penyertaan modal saham dalam perusahaan-perusahaan, dan memberikan jaminan jangka menengah/panjang serta menyediakan bantuan keahlian yang diberikan untuk mengatasi masalah manajemen perusahaan bersangkutan;

3. M embantu menciptakan kondisi berusaha yang baik bagi pengusaha kecil dan menengah agar mereka dapat tumbuh menjadi pengusaha yang dapat diandalkan.

Sedangkan manfaat adanya usaha modal ventura adalah :23

1. Kegiatan usaha dapat ditingkatkan.

2. Kemungkinan berhasilnya usaha lebih besar.

3. Peningkatan efisiensi pemasaran produk.

4. Peningkatan bankabilitas.

5. Peningkatan tingkat likuiditas.

6. Peningkatan tingkat rentabilitas.

\section{Kesimpulan}

Perusahaan modal ventura syariah adalah usaha pembiayaan melalui kegiatan investasi dan atau pelayanan jasa yang dilakukan dalam jangka waktu tertentu dalam rangka pengembangan usaha pasangan usaha yang dilaksanakan berdasarkan prinsip syariah. M odal ventura dalam usahanya menjalankan proses investasi yang dimulai dari masuknya pemodal dengan membentuk suatu pool of funds, proses pembiayaan pada Perusahaan Pasangan Usaha (PPU) sampai proses penarikan kembali penyertaan tersebut (di investasi). Modal ventura memiliki karateristik bantuan finansial jangka panjang namun bersifat tidak permanen (berjangka maksimal 10 tahun).

${ }^{22}$ Hoedhiono Kadarisman, M odal V entura A Iternatif Pembiayaan U saha M asa Depan (Jakarta: IBEC, 1995), 145

${ }^{23}$ M artono, Bank dan Lembaga K euangan Lain (Y ogyakarta: Ekonasia K ampus Fakultas Ekonomi UII, 2004), 127 
Mekanisme kerja model ventura adalah menyalurkan dana melalui investasi kepada PPU dan pada akhir waktu investasi Modal Ventura melakukan devistasi. Sumber modal ventura sangat beragam dapat diperoleh dari perorangan, institusi pemerintah maupun institusi swasta. Pembiayaan modal ventura syariah berupa musyarakah, mudharabah maupun murabahah.

Modal ventura sangat bermanfat bagi keberlangsungan dunia usaha, karena meningkatkan efisiensi pemasaran produk, peningkatan bankabilitas perusahaan, peningkatan tingkat likuiditas perusahaan, dan peningkatan tingkat rentabilitas perusahaan.

\section{D aftar Rujukan}

Fuady, Munir, Hukum tentang pembiayaan dalam teori dan praktek (leasing, factoring, modal ventura, pembiayaan konsumen, kartu kredit), B andung: PT . Citra A ditya B akti, 1999

Kadarisman, Hoedhiono, Modal Ventura Alternatif Pembiayaan Usaha Masa Depan, Jakarta: IBEC, 1995

Muliya, Liya Sukma, Perusahaan Modal Ventura Dalam Perspektif Hukum Bisnis Dan Hukum Islam, B andung: Fakultas Hukum U niversitas Islam B andung, 2008

Martono, Bank dan Lembaga Keuangan Lain, Yogyakarta: Ekonasia Kampus Fakultas Ekonomi UII, 2004

Pandia, Frianto, Lembaga K euangan Syariah, Jakarta: Rineka Cipta, 2005

Rivai, V eithzal, B ank dan Finance Institution M anagement, J akarta: PT. R ajaG rafindo, 2007

Soemitra, Andi, Bank dan Lembaga Keuangan Syariah, Jakarta: Kencana Prenada M edia Group, 2012

http://www.ojk.go.id/id/kanal/iknb/data-data statistik/lembaga pembiayaan/Pages/Statistik-

Lembaga-Pembiayaan-Periode-A pril-2016.aspx 